\title{
Chiral Resolution, Absolute Configuration Assignment, and Genotoxicity Evaluation of Racemic 3,4-Dihydroquinazoline as a Novel Anticancer Agent
}

\author{
Junseong Ahn, ${ }^{1}$ Dohyeong Ko, ${ }^{1}$ Seyoung Yang, ${ }^{1}$ Kwang H. Moon, ${ }^{1}$ Jiwon Woo, ${ }^{1}$ Ho Yoo, ${ }^{2}$ \\ Joohoon Ahn, ${ }^{2}$ Jeong H. Lee, ${ }^{3,4}$ Kyung S. Chung, ${ }^{3}$ Kyung-T. Lee $\mathbb{D}^{3,4}$ and Jae Y. Lee $\mathbb{D}^{1,5}$ \\ ${ }^{1}$ Research Institute for Basic Sciences and Department of Chemistry, College of Sciences, Kyung Hee University, \\ Seoul 02447, Republic of Korea \\ ${ }^{2}$ ONCOZEN Co.,Ltd., ONCOZEN RéD Center, C-713, Beobwon-ro 11-gil, Songpa-gu, Seoul 05836, Republic of Korea \\ ${ }^{3}$ Department of Pharmaceutical Biochemistry, College of Pharmacy, Kyung Hee University, Seoul 02447, Republic of Korea \\ ${ }^{4}$ Department of Life and Nanopharmaceutical Sciences, Graduate School, Kyung Hee University, Seoul 02447, Republic of Korea \\ ${ }^{5}$ KHU-KIST Department of Converging Science and Technology, Graduate School, Kyung Hee University, \\ Seoul 02447, Republic of Korea
}

Correspondence should be addressed to Kyung-T. Lee; ktlee@khu.ac.kr and Jae Y. Lee; ljy@khu.ac.kr

Received 12 September 2021; Accepted 1 October 2021; Published 25 October 2021

Academic Editor: Joaquin Campos

Copyright ( 2021 Junseong Ahn et al. This is an open access article distributed under the Creative Commons Attribution License, which permits unrestricted use, distribution, and reproduction in any medium, provided the original work is properly cited.

If a new drug candidate will be a mixture of enantiomers, both enantiomers should be separately studied for at least latent genotoxicity as early as possible since the thalidomide tragedy. Our group has recently reported that KCP-10043F $(\mathbf{O Z}-\mathbf{0 0 1})$ as a racemate $( \pm)$-3,4-dihydroquinazoline derivative strongly represses the proliferation of human A549 lung cancer cells by caspasemediated apoptosis via STAT3 inactivation. To investigate the possible teratological effects of the two enantiomers of a racemic KCP$10043 \mathrm{~F}$, therefore chiral resolution of $( \pm)-\mathrm{KCP}-10043 \mathrm{~F}$ was performed and subsequently followed by a series of chemical processes to afford the corresponding chiral diastereomers. By using ${ }^{1} \mathrm{H}$ NMR anisotropy method, the absolute configuration (+)-KCP-10043F and (-)-KCP-10043F could be assigned as $S$ and $R$ configuration, respectively. The bacterial reverse mutation test (Ames test) for racemate $( \pm)-\mathrm{KCP}-\mathbf{1 0 0 4 3 F}$ and its two enantiomers exhibited that all three stereoisomers were found to be nongenotoxic against five bacterial strains with/without metabolic activation. In addition, $(R)-(-)$-KCP-10043F displayed almost equal anticancer activity to $(S)-(+)-$ KCP-10043F against three cancer cell lines. Based on these overall results, racemate KCP-10043F (OZ-001) could be used for our ongoing preclinical and clinical studies without the expensive asymmetric process and/or chiral separation.

\section{Introduction}

The significance of chirality in drug design and development cannot be understated [1]. About more than half of the drugs currently in use are chiral compounds and near $90 \%$ of the last ones are marketed as racemates (or racemic mixtures) [2]. Although the enantiomers of chiral drugs have the same chemical connectivity of atoms, they would exhibit marked differences in their pharmacology, toxicology, pharmacokinetics, metabolism, etc.: while one enantiomer is beneficial to the body, the other enantiomer can be highly toxic to the body [3]. A well-known example of enantiomer-related toxicity is the $R$ - and $S$-enantiomers of thalidomide [4]. The $R$-enantiomer is an effective sedative, but the $S$-enantiomer is known to cause teratogenic birth defects. During the late 1950s and early 1960s, thalidomide produced birth defects in children born to women who took the racemic mixture during pregnancy [5]. According to the United States Food and Drug Administration (US FDA) guidelines, it is mandatory to separate chiral drugs before they are marketed [6]. Rigorous justification is needed for the market approval of racemic drugs. FDA has approved the marketing of some 
racemic drugs such as flecainide, ketorolac, and prilocaine [7]. In this case, both enantiomers have equal therapeutic potency without any toxicity or they are known to racemize in the body.

In our previous work, a family of 3,4-dihydroquinazoline derivatives was discovered as a promising anticancer agent [8-10], among which KCP-10043F (OZ-001) represses the proliferation of human A549 lung cancer cells by caspasemediated apoptosis via STAT3 inactivation [11, 12]. This compound was a racemate $( \pm)$-3,4-dihydroquinazoline derivative with a single chiral center (Figure 1). In this work, we separated the racemate $( \pm)-\mathbf{K C P}-\mathbf{1 0 0 4 3 F}$ into two optically pure enantiomers (+)-KCP-10043F and (-)-KCP-10043F, which were assigned for their absolute configuration by the formation of chiral diastereomers and ${ }^{1} \mathrm{H}$ NMR anisotropy method. The bacterial reverse mutation test (Ames test) for two enantiomers and a racemate of $\mathbf{K C P}-\mathbf{1 0 0 4 3 F}$ was performed to investigate their latent genotoxicity as well as their anticancer activities.

\section{Materials and Methods}

2.1. Chiral Resolution. Two enantiomers of racemate ( \pm )-KCP-10043F (OZ-001) were separated by a Shimadzu LC-20AD (CP-HPLC-08) with CHIRALPAK IA column $(2.5 \mathrm{~cm}$ I.D. $\times 25 \mathrm{~cm} \mathrm{~L}, 10 \mu \mathrm{m}$ particle size $)$ using ethanol $(100 \%)$ as a mobile phase with a flow rate of $25 \mathrm{~mL} / \mathrm{min}$ and a detection wavelength of $214 \mathrm{~nm}$ at a temperature of $38^{\circ} \mathrm{C}$. Each separated enantiomer was analyzed by a Shimadzu LC20AD (CP-HPLC-08) with CHIRALPAK IA-3 (IA30CEOB011) column $(0.46 \mathrm{~cm} \mathrm{I.D.} \times 25 \mathrm{~cm} \mathrm{L.})$ using ethanol/ diethylamine $(100 / 0.1: \mathrm{v} / \mathrm{v})$ as a mobile phase with a flow rate of $0.5 \mathrm{~mL} / \mathrm{min}$ and a detection wavelength of $214 \mathrm{~nm}$ at a temperature of $35^{\circ} \mathrm{C}$.

2.2. Chemistry. Analytical thin-layer chromatography (TLC) was performed on silica gel precoated on glass-backed plates (Fluka Kieselgel $60 \mathrm{~F}_{254}$, Merck). An UV light $(\lambda=254 \mathrm{~nm})$ was used for the detection. Flash chromatography was performed on silica gel 60 (particle size 230-400 mesh, Merck). Commercially available reactants were supplied by Sigma-Aldrich and used without further purification.

Optical rotations were obtained with an Autopol III Automatic Polarimeter (Rudolph Research Analytical). Experimental electronic circular dichroism (ECD) spectrum was recorded on a Jasco J-715 circular dichroism (CD) spectropolarimeter (Jasco). Melting points were measured on a MEL-TEMP ${ }^{\circledR} 3.0$ capillary melting point apparatus (Sigma-Aldrich). ${ }^{1} \mathrm{H}$ NMR spectra on a Bruker Avance DXR $400(400 \mathrm{MHz})$ spectrometer (Bruker) and Jeol JNM-ECZR $500 \mathrm{MHz}$ spectrometer were recorded in $\mathrm{CDCl}_{3}$. Chemical shifts were reported in $\delta(\mathrm{ppm})$ units relative to tetramethylsilane (TMS).

2.3. Preparation of Compound ( \pm )-6. To a solution of $( \pm)-\mathbf{5}$ $(1.86 \mathrm{~g}, 3.57 \mathrm{mmol})$ in $\mathrm{THF} / \mathrm{H}_{2} \mathrm{O}(1: 1, \mathrm{v} / \mathrm{v}, 15 \mathrm{~mL}) \mathrm{LiOH}$ $(0.45 \mathrm{~g}, 10.71 \mathrm{mmol})$ was added. The reaction mixture was stirred at room temperature for $4 \mathrm{~h}$ and concentrated under reduced pressure. The reaction mixture was dissolved with a mixed solvent of DCM $(20 \mathrm{~mL})$ and water $(20 \mathrm{~mL})$. The extracted aqueous layer was acidified by $0.5 \mathrm{~N} \mathrm{HCl}(\mathrm{pH}=4)$ and extracted with DCM $(25 \mathrm{~mL})$. The extracted organic layer was dried with $\mathrm{MgSO}_{4}$ and evaporated under reduced pressure to give the desired product $( \pm)-6 \quad(180 \mathrm{mg},>99 \%):{ }^{1} \mathrm{H}$ NMR $(400 \mathrm{MHz}$, $\left.\mathrm{CDCl}_{3}\right) \delta 12.42($ br s, $1 \mathrm{H}), 7.89(\mathrm{~d}, J=8.0 \mathrm{~Hz}, 1 \mathrm{H})$, 7.35-7.31 (m, 1H), 7.18-7.14 (m, 3H), 7.13-7.07 (m, 3H), 6.31 (br s, $1 \mathrm{H}), 5.18$ (dd, $J=10.4$ and $4.8 \mathrm{~Hz}, 1 \mathrm{H}), 3.59$ (br s, $1 \mathrm{H}), 3.27$ (br s, $2 \mathrm{H}), 2.96(\mathrm{~s}, 6 \mathrm{H}), 2.93-2.89(\mathrm{~m}, 3 \mathrm{H})$, $2.68-2.63(\mathrm{~m}, 1 \mathrm{H}), 2.47-2.44(\mathrm{~m}, 1 \mathrm{H}), 2.06(\mathrm{~s}, 1 \mathrm{H})$, $1.86-1.81(\mathrm{~m}, 5 \mathrm{H}), 1.76-1.72(\mathrm{~d}, J=13.2 \mathrm{~Hz}, 2 \mathrm{H})$, $1.38-1.28(\mathrm{~m}, 4 \mathrm{H}), 1.26-1.21 \quad(\mathrm{~m}, 2 \mathrm{H}) ;{ }^{13} \mathrm{C} \mathrm{NMR}$ $\left(100 \mathrm{MHz}, \mathrm{CDCl}_{3}\right) \delta 173.8,171.8,159.4,153.4,147.6$, $140.3,132.4,129.2,128.6,126.1,125.4,123.9,118.8,61.9$, 50.6, 43.8, 40.6, 38.1, 36.5, 34.1, 34.1, 27.3, 26.6, 25.8 .

2.4. Preparation of Compound $\mathbf{8 a - 8 b}$. To a solution of

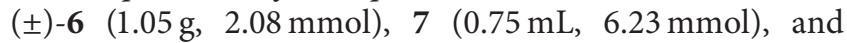
DMAP $(0.13 \mathrm{~g}, 1.04 \mathrm{mmol})$ in dry dichloromethane $(20 \mathrm{~mL})$ a solution of $\mathrm{EDC} \cdot \mathrm{HCl}(0.48 \mathrm{~g}, 2.49 \mathrm{mmol})$ in dry dichloromethane $(5 \mathrm{~mL})$ was added dropwise at $0^{\circ} \mathrm{C}$. The reaction mixture was stirred at room temperature for $3 \mathrm{~h}$ in argon atmosphere and concentrated under reduced pressure. The reaction mixture was dissolved with a mixed solvent of EtOAc $(30 \mathrm{~mL})$ and water $(3 \times 10 \mathrm{~mL})$. The extracted combined organic layer was dried with $\mathrm{MgSO}_{4}$ and evaporated under reduced pressure. The crude product was then purified by flash column chromatography (EA:DCM: hexane:EtOH = 2:2:12:1) to afford $(S, 4 R)-\mathbf{8 a}$ and $(S, 4 S)-\mathbf{8 b}$ (1:1 ratio, $899 \mathrm{mg}, 71 \%)$, for $(S, 4 R)-8$ a. ${ }^{1} \mathrm{H}$ NMR $(500 \mathrm{MHz}$, $\left.\mathrm{CDCl}_{3}\right) \delta 7.36-7.35(\mathrm{~m}, 1 \mathrm{H}), 7.35-7.33(\mathrm{~m}, 2 \mathrm{H}), 7.32-7.31$ $(\mathrm{m}, 1 \mathrm{H}), 7.29-7.27(\mathrm{~m}, 1 \mathrm{H}), 7.15(\mathrm{td}, J=7.9$ and $1.3 \mathrm{~Hz}, 1 \mathrm{H})$, 7.02-6.89 (m, 3H), 6.94-6.93 (m, 1H), 6.88-6.86 (m, 3H), $5.99(\mathrm{q}, J=6.6 \mathrm{~Hz}, 1 \mathrm{H}), 5.04(\mathrm{dd}, J=11.2$ and $4.4 \mathrm{~Hz}, 1 \mathrm{H})$, 4.28 (br s, 1H), 3.66 (br s, $1 \mathrm{H}), 2.97$ (s, 6H), 2.81 (d, $J=13.2 \mathrm{~Hz}, 1 \mathrm{H}), 2.72-2.67(\mathrm{~m}, 2 \mathrm{H}), 2.54-2.50(\mathrm{~m}, 1 \mathrm{H})$, 2.41-2.36 (m, 1H), 2.07 (s, 3H), 1.81-1.78 (m, 4H), 1.72-1.70 $(\mathrm{m}, 1 \mathrm{H}), 1.57(\mathrm{~d}, J=6.6 \mathrm{~Hz}, 4 \mathrm{H}), 1.35-1.28(\mathrm{~m}, 4 \mathrm{H})$, $1.25-1.23(\mathrm{~m}, 2 \mathrm{H}), 1.21-1.15(\mathrm{~m}, 1 \mathrm{H})$.

2.5. Preparation of Compound (R)-6. To a solution of $(S, 4 R)$ $8 \mathbf{a}(0.17 \mathrm{~g}, 0.28 \mathrm{mmol})$ in $\mathrm{THF} / \mathrm{H}_{2} \mathrm{O}(1: 1, \mathrm{v} / \mathrm{v}, 8 \mathrm{~mL}) \mathrm{LiOH}$ (70 $\mathrm{mg}, 1.67 \mathrm{mmol}$ ) was added. The reaction mixture was stirred at room temperature for $72 \mathrm{~h}$ and concentrated under reduced pressure. The reaction mixture was dissolved with a mixed solvent of DCM $(10 \mathrm{~mL})$ and water $(10 \mathrm{~mL})$. The extracted aqueous layer was acidified with $0.5 \mathrm{~N} \mathrm{HCl}$ until the $\mathrm{pH}$ of the aqueous layer was 2, extracted with DCM $(15 \mathrm{~mL})$. The extracted organic layer was dried with $\mathrm{MgSO}_{4}$ and evaporated under reduced pressure to give desired product $(R)-6(140 \mathrm{mg},>99 \%):{ }^{1} \mathrm{H} \mathrm{NMR}\left(500 \mathrm{MHz}, \mathrm{CDCl}_{3}\right)$ $\delta 12.86(\mathrm{br} \mathrm{s}, 1 \mathrm{H}), 7.93(\mathrm{~d}, J=8.3 \mathrm{~Hz}, 1 \mathrm{H}), 7.35-7.28(\mathrm{~m}, 1 \mathrm{H})$, 7.18-7.12 (m, 3H), 7.11-7.08 (m, 3H), 6.27 (br s, $1 \mathrm{H}), 5.18$ (dd, $J=10.8$ and $5.0 \mathrm{~Hz}, 1 \mathrm{H}$ ), 3.52 (br s, $1 \mathrm{H}), 3.28$ (br s, $2 \mathrm{H}$ ), $2.96(\mathrm{~s}, 6 \mathrm{H}), 2.92-2.87$ (m, 3H), 2.64-2.60 (m, 1H), 2.48-2.42 


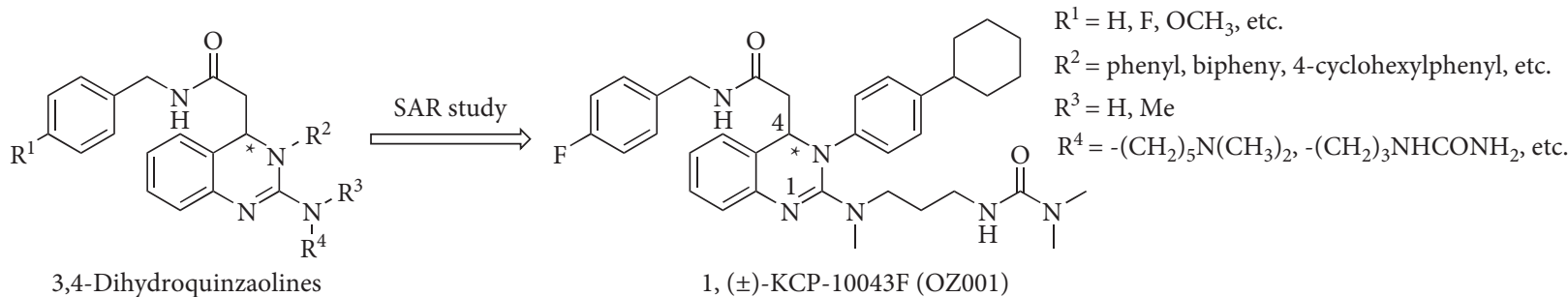

Figure 1: Chemical structures of 3,4-dihydroquinazolines and KCP-10043F (OZ-001).

$(\mathrm{m}, 1 \mathrm{H}), 1.96$ (br s, 1H), 1.86-1.78 (m, 5H), 1.73 $(\mathrm{d}, J=12.7 \mathrm{~Hz}, 2 \mathrm{H}), 1.38-1.28(\mathrm{~m}, 4 \mathrm{H}), 1.25-1.19(\mathrm{~m}, 2 \mathrm{H})$.

2.6. Preparation of Compound 1 [(R)-(-)-KCP-10043F (OZ001)]. To a solution of $(R)-6(0.26 \mathrm{~g}, 0.50 \mathrm{mmol})$ and TEA $(0.09 \mathrm{~mL}, 0.64 \mathrm{mmol})$ in DMF $(20 \mathrm{~mL})$ pivaloyl chloride $(0.073 \mathrm{~mL}, 0.60 \mathrm{mmol})$ was added dropwise. The reaction mixture was stirred for $3 \mathrm{~h}$ at room temperature. The reaction mixture was treated with 4 -fluorobenzylamine $(0.053 \mathrm{~mL}, 0.46 \mathrm{mmol})$ and TEA $(0.07 \mathrm{~mL}, 0.50 \mathrm{mmol})$, further stirred for $2 \mathrm{~h}$ at room temperature. The reaction mixture was dissolved with a mixed solvent of DCM $(20 \mathrm{~mL})$ and water $(20 \mathrm{~mL})$. The extracted combined organic layer was dried with $\mathrm{MgSO}_{4}$ and evaporated under reduced pressure. The crude product was then purified by flash column chromatography (EA:DCM: hexane: $\mathrm{EtOH}=2: 2: 12: 1)$ to provide the final product $\mathbf{1}$ $[(R)-(-)-$ KCP-10043F (OZ-001)] as a white solid (245 mg, $80 \%): \mathrm{mp} \quad 107-116^{\circ} \mathrm{C} ;{ }^{1} \mathrm{H}$ NMR $(400 \mathrm{MHz}$, $\left.\mathrm{CDCl}_{3}\right) \delta 7.29-7.26(\mathrm{br} \mathrm{m}, 2 \mathrm{H}), 7.16-7.14(\mathrm{~m}, 2 \mathrm{H})$, 7.07-7.03 (m, 3H), 6.98-6.93 (m, 5H), 6.90-6.88 (m, 1H), $5.21(\mathrm{dd}, J=10.4$ and $4.8 \mathrm{~Hz}, 1 \mathrm{H}), 4.45-4.37(\mathrm{~m}, 2 \mathrm{H}), 4.16$ (br, $1 \mathrm{H}), 3.41$ (br s, $1 \mathrm{H}), 3.02-2.88(\mathrm{~m}, 2 \mathrm{H}), 2.85(\mathrm{~s}, 6 \mathrm{H})$, $2.58(\mathrm{dd}, J=14.4$ and $10.4 \mathrm{~Hz}, 1 \mathrm{H}), 2.43-2.38(\mathrm{~m}, 5 \mathrm{H})$, $1.83-1.81(\mathrm{~m}, 4 \mathrm{H}), 1.75-1.73(\mathrm{~m}, 3 \mathrm{H}), 1.40-1.32(\mathrm{~m}, 4 \mathrm{H})$, $1.28-1.21(\mathrm{~m}, 2 \mathrm{H}) ;{ }^{13} \mathrm{C} \mathrm{NMR}\left(100 \mathrm{MHz}, \mathrm{CDCl}_{3}\right) \delta 170.0$, $158.9,154.5,144.0,143.7,143.4,134.7,129.9,129.8$, $127.9,127.6,126.6,125.1,121.9,121.8,115.2,115.0,61.2$, 43.8, 42.8, 41.4, 39.6, 37.2, 36.3, 34.5, 34.4, 27.1, 26.9, 26.1; low MS (ES): $\mathrm{m} / \mathrm{z} 613.4[\mathrm{M}+\mathrm{H}]+$; HRMS (FAB): $\mathrm{m} / \mathrm{z}$ calcd for $\mathrm{C}_{36} \mathrm{H}_{46} \mathrm{~N}_{6} \mathrm{O}_{2} \mathrm{~F}[\mathrm{M}+\mathrm{H}]^{+}$613.3661, found 613.3660; $[\alpha]_{D}^{26}$ of $-261^{\circ}\left(\right.$ c $\left.0.003, \mathrm{CHCl}_{3}\right)$.

2.7. Time-Dependent Density Functional Theory (TDDFT) Calculation. The simulated ECD spectrum of $(R)-(-)$-KCP$10043 \mathrm{~F}$ was calculated with TDDFT approach at B3LYP/ TZVP level based on the structure optimized at the same level in Gaussian09 program package [13].

2.8. Ames Test. The Ames test for mutagenicity evaluation was performed by using Ames $\mathrm{MPF}^{\mathrm{TM}}$ Penta 1 Mutagenicity Assay Kit (Xenometrix; B10-513-S1-P) [14, 15]. Each compound was studied at concentrations of $20 \sim 5,000 \mu \mathrm{g} / \mathrm{mL}$ in the presence or absence of metabolic activation ( $S 9$ fraction).
2.9. MTT Assay (Anticancer Activity). Human lung adenocarcinoma A549 cells, human colorectal adenocarcinoma HT-29 cells, and human pancreatic cancer PANC-1 cells were obtained from the Korean Cell Line Bank (Seoul, Korea). Cells were cultured in RPMI 1640 supplemented with $10 \%$ heat-inactivated FBS, penicillin $(100 \mathrm{U} / \mathrm{mL})$, and streptomycin sulfate $(100 \mu \mathrm{g} / \mathrm{mL})$. Cells were cultured at $37^{\circ} \mathrm{C}$ in an atmosphere of $5 \% \mathrm{CO}_{2}$.

The cancer cells $\left(5 \times 10^{4} / \mathrm{mL}\right)$ were seeded in each well containing $100 \mu \mathrm{L}$ of RPMI medium supplemented with $10 \%$ FBS in a 96-well plate. Various concentrations of each compound were added and incubated for $24 \mathrm{~h}$. MTT ( $5 \mathrm{mg} /$ $\mathrm{mL}$ stock solution) was added and the plates were incubated for an additional $4 \mathrm{~h}$. The medium was discarded and formazan blue, which was formed in the cells, was dissolved with $100 \mu \mathrm{L}$ DMSO. The optical density was measured at $540 \mathrm{~nm}$ by an automatic microplate reader (Molecular Devices Corp).

\section{Results and Discussion}

3.1. Chiral Resolution. Firstly, we separated racemate $( \pm)-\mathrm{KCP}-10043 \mathrm{~F}$ with the aid of the chiral technique of supercritical fluid chromatography (SFC) to get optically pure enantiomers (+)-KCP-10043F and (-)-KCP-10043F with $>99 \%$ enantiomeric excess $(e e)$ and purity $>99 \%$ (Figure 2) $[16,17]$. The specific optical rotations $[\alpha]_{D}^{22}$ of (+)-KCP-10043F (Figure 2(b)) and (-)-KCP-1-170043F (Figure 2(c)) were determined to be $+273^{\circ}\left(c 0.01, \mathrm{CHCl}_{3}\right)$ and $-281^{\circ}$ (c $\left.0.01, \mathrm{CHCl}_{3}\right)$, respectively.

3.2. Absolute Configuration Assignment. Our method for absolute configuration assignment of each enantiomer was based on the direct covalent diastereomer formation between a racemic compound and a chiral selector [18]. For this matter, racemic ester $( \pm)-5$ was routinely prepared according to our previously reported method (Scheme 1) [11]. Treatment of $( \pm)-\mathbf{5}$ with $\mathrm{LiOH}$ in THF- $\mathrm{H}_{2} \mathrm{O}(1: 1)$ solvent at room temperature produced racemic acid $( \pm)-6$ in quantitative yield. Subsequent esterification of $( \pm)-6$ with chiral (S)-(-)-1-phenylethanol 7 (purity $\geq 99.0 \%$ ) using 1ethyl-3-(3-dimethylaminopropyl)carbodiimide hydrochloride (EDC.HCl) and 4-dimethylaminopyridine (DMAP) coupling condition yielded a mixture of diastereomeric esters $\mathbf{8 a}$ and $\mathbf{8 b}$ with a ratio of $1: 1\left({ }^{1} \mathrm{H} \mathrm{NMR}\right)$ in $71 \%$ yield (Supplemental data: Figure S1) [19]. The mixture was easily separated by column chromatography on normal silica gel 


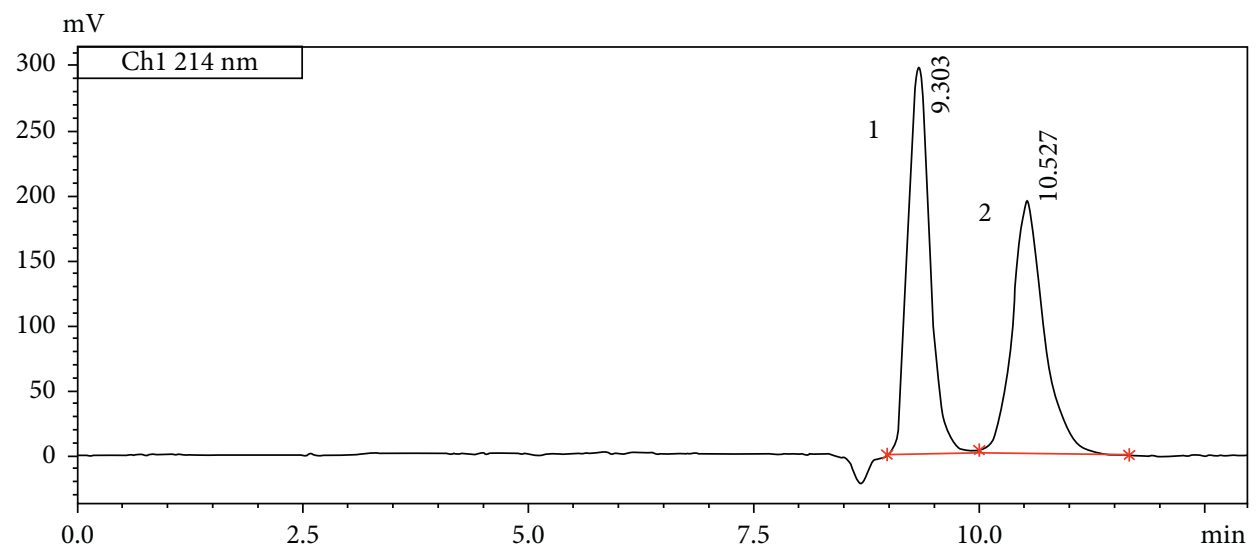

(a)

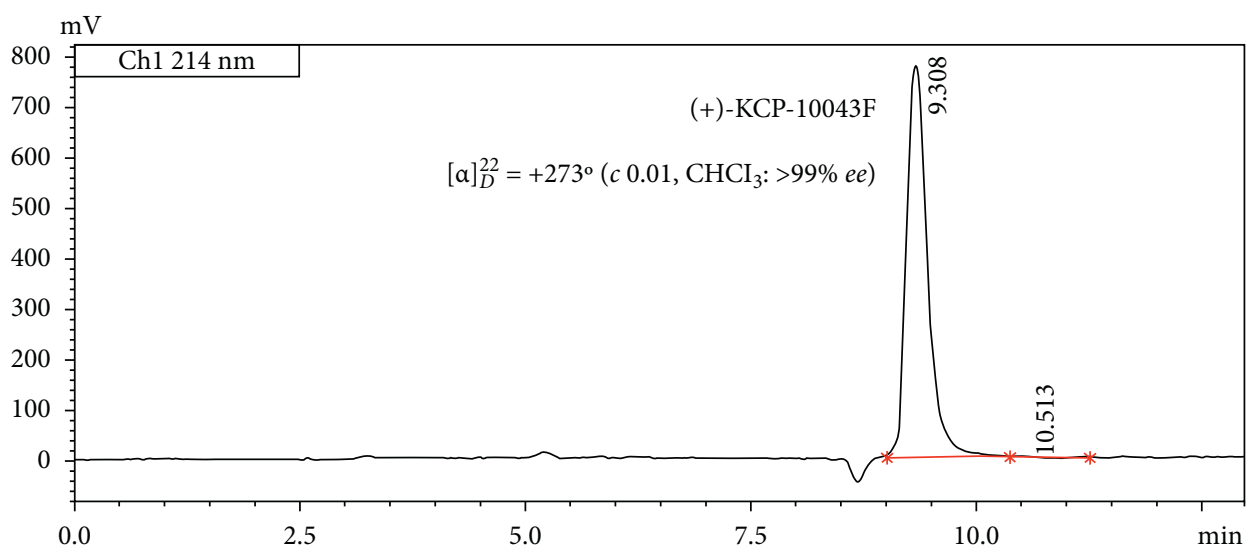

(b)

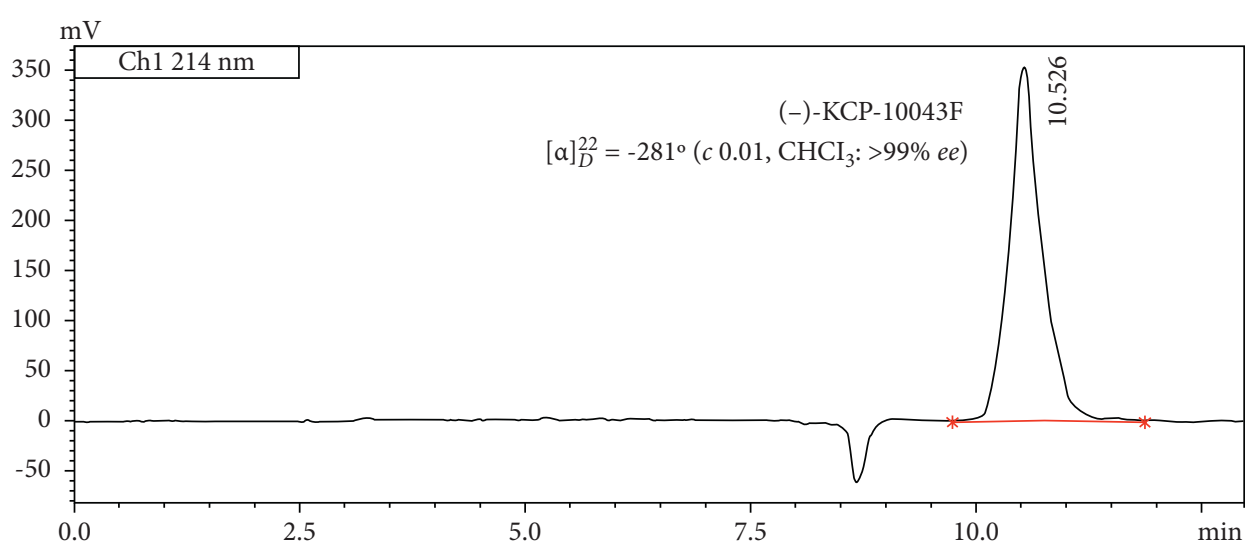

(c)

Figure 2: Chiral HPLC spectra, specific optical rotations, and enantiomeric excess $(e e)$ of the racemate $( \pm)-\mathbf{K C P}-\mathbf{1 0 0 4 3 F}(\mathbf{O Z}-\mathbf{0 0 1})$ and its two enantiomers: (a) racemate ( \pm )-KCP-10043F (OZ-001); (b) (+)-KCP-10043F; (c) (-)-KCP-10043F.

(EtOAc: $\mathrm{CH}_{2} \mathrm{Cl}_{2}:$ hexane:EtOH $=2: 2: 12: 1$ ) to provide the first eluted ester 8a (Supplemental data: Figure S2) and the second one 8b (Supplemental data: Figure S3) as shown in Scheme 1. To prepare the enantiopure amide 1 (KCP10043F : OZ-001), the first eluted ester 8a was treated with $\mathrm{LiOH}$ in $\mathrm{THF}-\mathrm{H}_{2} \mathrm{O}(1: 1)$ to afford chirally pure acid 5 in quantitative yield. This acid $\mathbf{5}$ was treated with pivaloyl chloride and triethylamine (TEA) in DMF to provide a mixed carboxylic acid anhydride in situ [20], which was directly coupled with 4-fluorobenzylamine 9 in the presence of TEA to afford the enantiopure amide 1, (-)-KCP-10043F (OZ-001) in $80 \%$ yield: $[\alpha]_{D}^{26}$ of $-261^{\circ}\left(c 0.003, \mathrm{CHCl}_{3}\right)$ and $95.57 \pm 0.02 \%$ ee based on the same chiral HPLC analysis (Supplemental data: Figure S4). The (+)-KCP-10043F (OZ001) could be also prepared in $78 \%$ yield starting from the second eluted ester $\mathbf{8 b}$ by using the same procedure.

To assign the absolute configuration at C-4 position of the quinazoline scaffold, we decided to investigate the ${ }^{1} \mathrm{H}$ NMR 

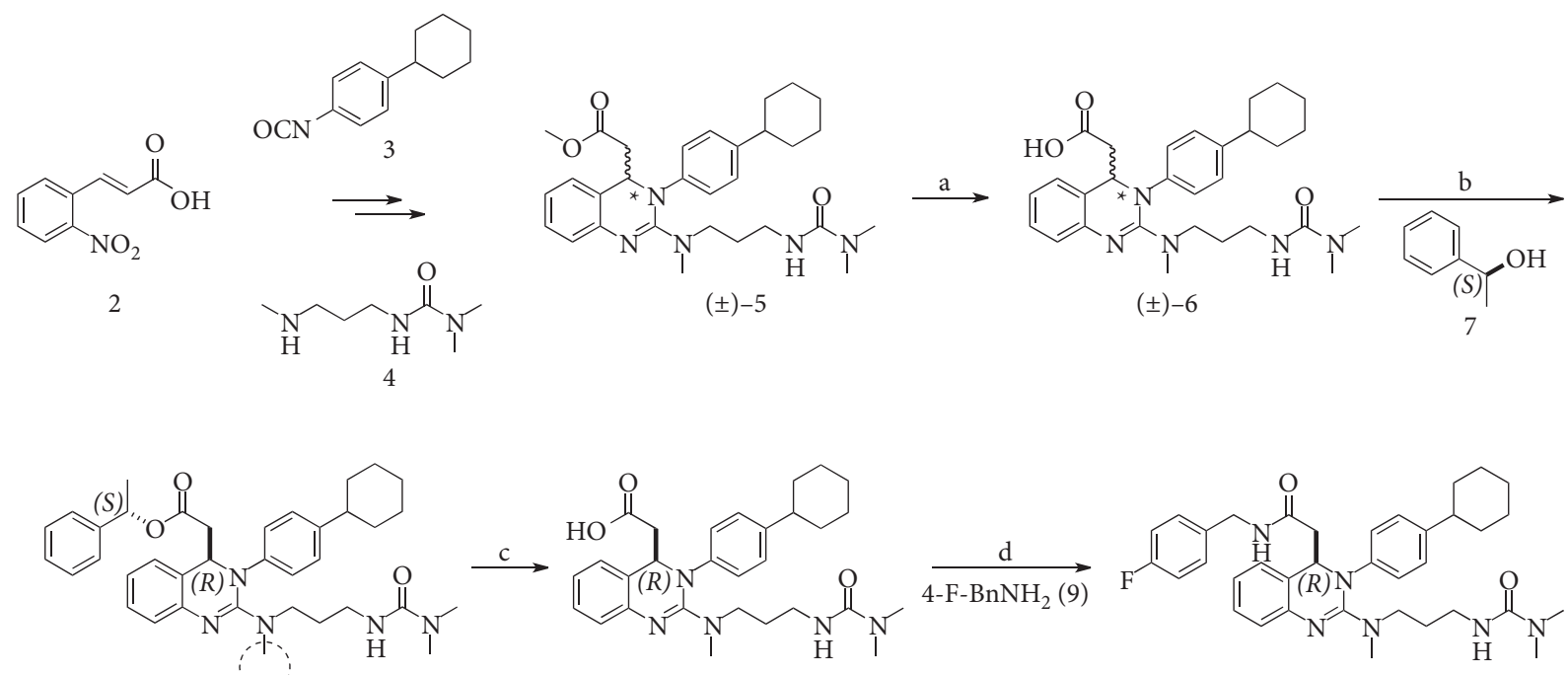

$(S, 4 R)-8 \mathrm{a}$ : chemical shift of $\mathrm{Me}=2.07 \mathrm{ppm}$

$(R)-6$

1, (R)-(-)-KCP-10043F (OZ-001)

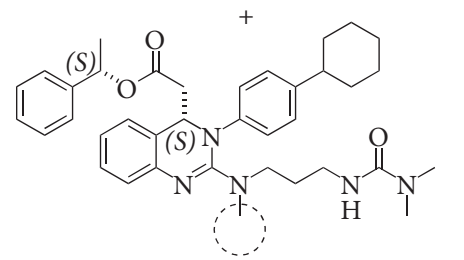

$(S, 4 S)-8 \mathrm{~b}$ : chemical shift of $\mathrm{Me}=2.57 \mathrm{ppm}$

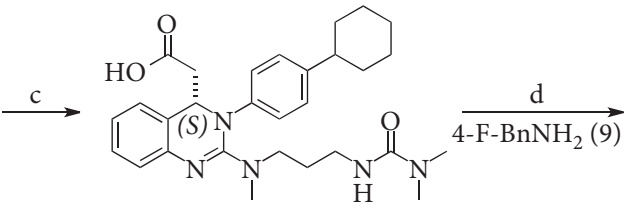

$(S)-6$

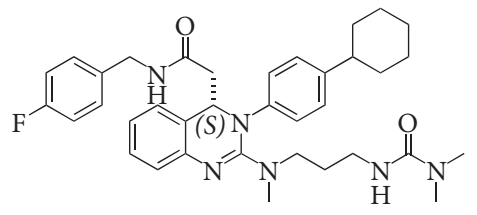

1, (S-(+)-KCP-10043F (OZ-001)

Scheme 1: Reagents and conditions: (a) $\mathrm{LiOH}, \mathrm{THF} / \mathrm{H}_{2} \mathrm{O}(1: 1), \mathrm{rt}, 4 \mathrm{~h}>99 \%$ (b) EDC.HCl, DMAP (cat.), $\mathrm{CH}_{2} \mathrm{Cl}_{2}, 0^{\circ} \mathrm{C}$ to $\mathrm{rt}, 3 \mathrm{~h} 71 \%$ (c) $\mathrm{LiOH}, \mathrm{THF} / \mathrm{H}_{2} \mathrm{O}(1: 1)$, rt, $72 \mathrm{~h}>99 \%$ for $(R)-6$ and (S)-6, respectively (d) pivaloyl chloride, TEA, DMF, rt, $3 \mathrm{~h}$; TEA, DMF, rt, $2 \mathrm{~h} 80$ and $78 \%$ for $(R)-(-)-1$ and $(S)-(+)-1$, respectively.

data of the separated esters $\mathbf{8} \mathbf{a}$ and $\mathbf{8 b}$, respectively. Before the analysis of the chemical shift data of ${ }^{1} \mathrm{H}$ NMR data, molecular mechanics (MM2) calculation and 3D-conformation analysis showed the considerable energy difference $(\Delta E=1.02 \mathrm{kcal} /$ mol) between $(S, 4 R)-\mathbf{8} \mathbf{a}$ and $(S, 4 S)-\mathbf{8 b}$ as shown in Figure 3. $N$-methyl group inside the white-colored dotted circle in $(S$, $4 R)-\mathbf{8 a}$ was completely located above the diamagnetic (shielding) zone of benzene ring ( $4 \AA$ : yellow-colored dotted circle) as shown in Figure 3(a), while the corresponding methyl group of $(S, 4 S)-\mathbf{8 b}$ was located within the paramagnetic (deshielding) zone (Figure 3(b)). According to the calculated anisotropic effect zone of benzene ring (Supplemental data: Figure S5) [21], the protons of the methyl groups of $(S, 4 R)-\mathbf{8 a}$ were anticipated to be largely upfield-shifted by the diamagnetic anisotropy effect of the phenyl moiety compared to those of $(S, 4 S)$-8b. In experimental ${ }^{1} \mathrm{H}$ NMR data, the chemical shifts of $N$-methyl groups in $(S, 4 R)$-8a and $(S, 4 S)$-8b exhibited 2.07 and $2.57 \mathrm{ppm}$, respectively (Figures 4(b) and 4(c)). Based on the consistency between the theoretical data and experimental data, the chiral center of (-)-KCP-10043F can be designated $R$ configuration and thus (+)-KCP-10043F can be readily assigned as $S$ configuration. Additionally, the ECD spectrum of (-)-KCP-10043F was further measured to afford a positive band at $268 \mathrm{~nm}$ and a negative band at $303 \mathrm{~nm}$, which was consistent with Gaussian TDDFT-calculated $R$ configuration of KCP-10043F as shown in Figure 5 [22].
3.3. Genotoxicity Evaluation. The Ames test was performed for mutagenicity evaluation of racemate $( \pm)$-KCP-10043F and its two enantiomers by using Ames $\mathrm{MPF}^{\mathrm{TM}}$ Penta 1 Mutagenicity Assay Kit (Xenometrix; B10-513-S1-P) $[14,15]$. The pre-incubation method, system metabolic activation (rat liver S9 fraction), seven positive controls (mutagens; refer to Figures S6-S10 of supplemental data), negative control (DMSO), and five bacterial strains $\{\mathrm{Sal}$ monella typhimurium strains (TA98, TA100, TA1535 and TA1537) and Escherichia coli WP2 uvrA[pKM101]\} were employed for the Ames test, in compliance with OECD Guideline 471 [23].

Each compound was studied at concentrations of $20 \sim 5,000 \mu \mathrm{g} / \mathrm{mL}$ in the presence or absence of metabolic activation (S9 fraction). As shown in Table 1, a revertant analysis showed no significant differences between the treatment doses $(20 \sim 5,000 \mu \mathrm{g} / \mathrm{mL})$ and the negative control (DMSO) regardless of $+\mathrm{S} 9$ and $-\mathrm{S} 9$, when compared to the positive control and included all strains of S. typhimurium and E. coli EP2 (Supplemental data: Figures S6-S10). All of these Ames test results showed that none of all stereoisomers of KCP10043F were genotoxic regarding frameshift mutations (TA98 and TA1537) and base pair substitutions \{TA100, TA1535 and E. coli WP2 uvrA[pKM101]\} regardless of the treatment dose [24]. 


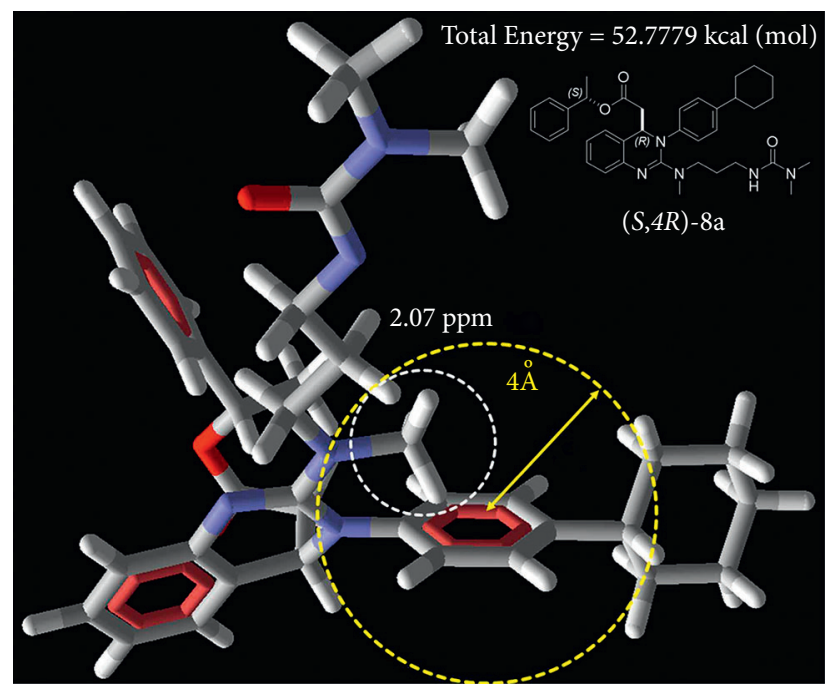

(a)

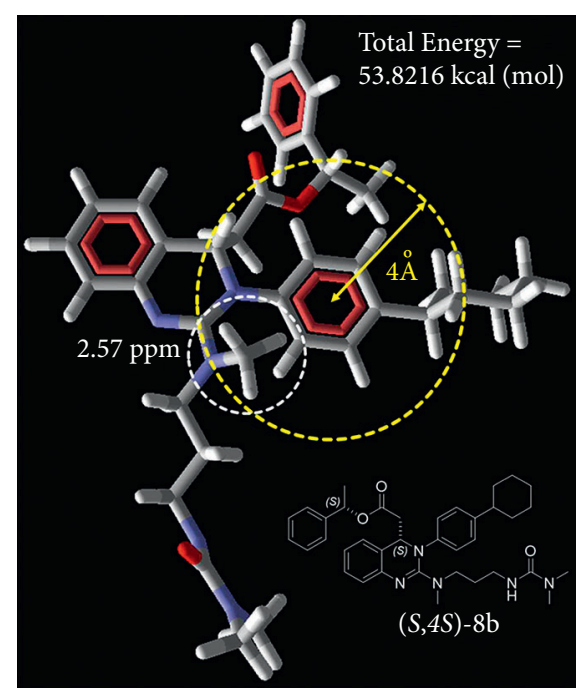

(b)

Figure 3: The most stable 3D-conformations of $(S, 4 R)-\mathbf{8 a}$ and $(S, 4 S)$-8b based on molecular mechanics (MM2) calculation. The calculated anisotropic effect zone of the benzene ring was represented by yellow-colored dotted circle (radius $4 \AA$ : $\Delta \delta=0.5$ ppm) according to the reported literature [21]. The chemical shifts of $N$-methyl groups inside white yellow-colored dotted circles in $(S, 4 R)-8 \mathbf{a}(\mathrm{a})$ and $(S, 4 S)-\mathbf{8 b}$ (b) exhibited 2.07 and $2.57 \mathrm{ppm}$.
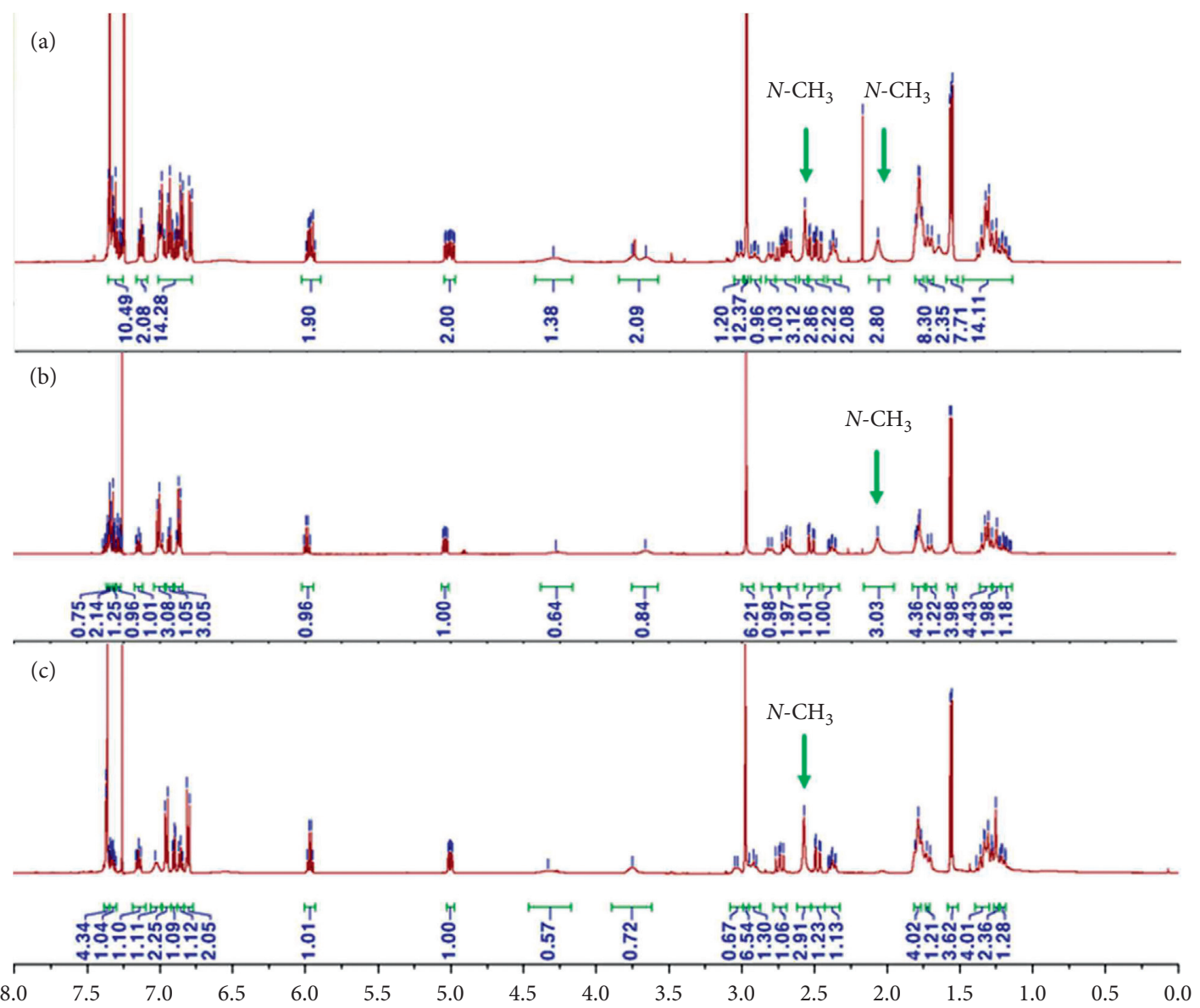

FIgURE 4: ${ }^{1} \mathrm{H}$ NMR spectra of (a) a mixture of diastereomeric esters $\mathbf{8 a}$ and $\mathbf{8 b}$; (b) $(S, 4 R)-\mathbf{8 a}$; (c) $(S, 4 S)-\mathbf{8 b}$. 


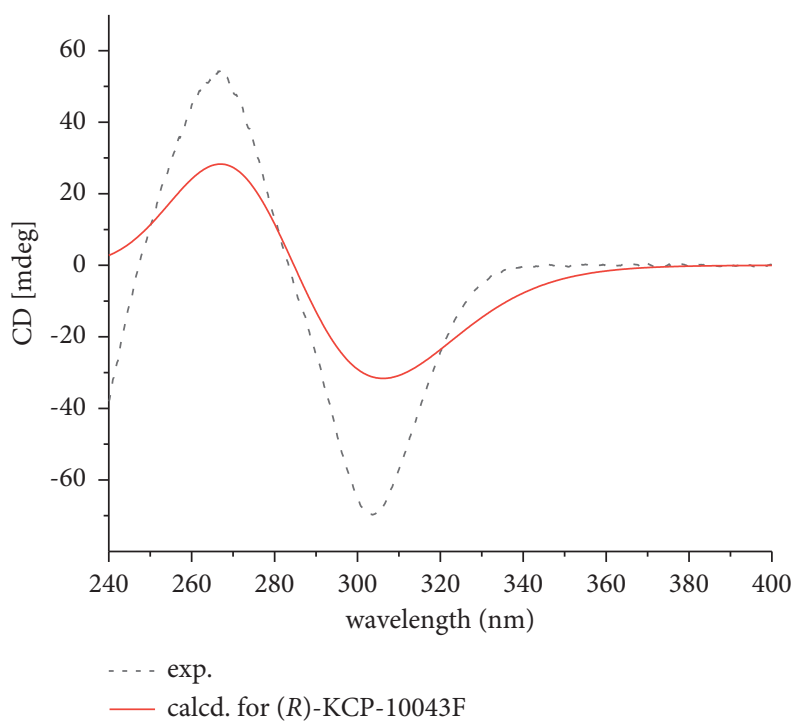

FIgURE 5: Experimental and TDDFT-calculated ECD spectrum of R-(-)-KCP-10043F.

TABLE 1: Non-mutagenic effects of racemic ( \pm )-KCP10043F and its two enantiomers in Salmonella typhimurium (TA) and Escherichia coli (E. coli) strains with $\mathrm{S} 9$ and without $S 9^{\mathrm{a}}$.

\begin{tabular}{|c|c|c|c|c|c|c|}
\hline \multirow[t]{2}{*}{ Strain } & \multicolumn{2}{|c|}{$\begin{array}{c}\text { Racemate }( \pm)-\mathrm{KCP}- \\
10043 \mathrm{~F}\end{array}$} & \multicolumn{2}{|c|}{$(R)-(-)-\mathrm{KCP} 10043 \mathrm{~F}$} & \multicolumn{2}{|c|}{$(\mathrm{S})-(+)-\mathrm{KCP} 10043 \mathrm{~F}$} \\
\hline & $+S 9$ & $-S 9$ & $+S 9$ & $-S 9$ & $+S 9$ & $-S 9$ \\
\hline \multicolumn{7}{|c|}{ Salmonella typhimurium (TA) } \\
\hline TA98 & $x$ & $\mathrm{x}$ & $\mathrm{x}$ & $\mathrm{x}$ & $\mathrm{x}$ & $\mathrm{x}$ \\
\hline TA100 & $\mathrm{x}$ & $\mathrm{x}$ & $\mathrm{x}$ & $\mathrm{x}$ & $\mathrm{x}$ & $\mathrm{x}$ \\
\hline TA1535 & $\mathrm{x}$ & $\mathrm{x}$ & $\mathrm{x}$ & $\mathrm{x}$ & $\mathrm{x}$ & $\mathrm{x}$ \\
\hline TA1537 & $\mathrm{x}$ & $\mathrm{x}$ & $\mathrm{x}$ & $\mathrm{x}$ & $\mathrm{x}$ & $\mathrm{x}$ \\
\hline \multicolumn{7}{|l|}{ Escherichia coli (E. Coli) } \\
\hline WP2 uvrA[pKM101] & $\mathrm{x}$ & $\mathrm{x}$ & $\mathrm{x}$ & $\mathrm{x}$ & $\mathrm{x}$ & $\mathrm{x}$ \\
\hline
\end{tabular}

${ }^{a}$ The results were obtained on the baselines by using the calculation of Xenometrix (Xenometric AG, Swiss); After calculating the baseline of DMSO (negative control), the compound was regarded as a mutagen when the induction is more than 2 -fold over the baseline and binomial $P$ value $\geq 0.99$; $\mathrm{x}$ means nongenotoxicity (negative response).

TABLE 2: Cytotoxicity of racemate $( \pm)-\mathrm{KCP}-10043 \mathrm{~F}$ and its two enantiomers against human cancer cell lines.

\begin{tabular}{lccc}
\hline \multirow{2}{*}{ Compound } & \multicolumn{3}{c}{ Cytotoxicity $\left(\mathrm{IC}_{50}: \mu \mathrm{M}\right)$} \\
& A549 $^{\mathrm{a}, \mathrm{b}}$ & HT-29 $^{\mathrm{c}}$ & PANC- $^{\mathrm{d}}$ \\
\hline$(R)-(-)-$ KCP10043F & $9.35 \pm 0.29$ & $5.52 \pm 0.46$ & $12.96 \pm 0.82$ \\
$(S)-(+)-$ KCP10043F & $9.78 \pm 0.11$ & $5.37 \pm 0.31$ & $10.60 \pm 0.13$ \\
\hline
\end{tabular}

${ }^{\mathrm{a}}$ Human lung adenocarcinoma cell line; ${ }^{\mathrm{b}} \mathrm{IC}_{50}$ of racemate $( \pm)-\mathrm{KCP}-$ $10043 \mathrm{~F}=7.0 \pm 0.1 \mu \mathrm{M}$; 'human colorectal adenocarcinoma cell line; ${ }^{\mathrm{d}} \mathrm{hu}-$ man pancreatic cancer cell line.

3.4. Anticancer Evaluation. The 3-(4,5-dimethylthiazol-2yl)-2,5-diphenyltetrazoliumbromide (MTT) method was used to evaluate the cytotoxic effects of $(R)-(-)$-KCP$10043 \mathrm{~F}$ and $(S)-(+)-\mathrm{KCP}-\mathbf{1 0 0 4 3 F}$ on three human cancer cell lines: lung cancer (A549), colon cancer (HT-29) and pancreatic cancer (PANC-1) [25]. As shown in Table 2, both enantiomers displayed almost equal cytotoxicity toward three cancer cell lines with micromolar $\mathrm{IC}_{50}$ values of PANC-1 $(10-12 \mu \mathrm{M})>$ A549 $(9 \mu \mathrm{M})>$ HT-29 $(5 \mu \mathrm{M})$ together with the reported data $\left(\mathrm{IC}_{50}=7 \mu \mathrm{M}\right)$ of racemate ( \pm )-KCP-10043F against A549 [11]. Therefore, it could be concluded that the anticancer activity of racemate $( \pm)-\mathbf{K C P}$ $10043 \mathrm{~F}$ was equally derived from both enantiomers.

\section{Conclusions}

$(R)-(-)-\mathrm{KCP} 10043 \mathrm{~F}$ and $(S)-(+)-\mathrm{KCP} 10043 \mathrm{~F}$ were successfully separated from racemate $( \pm)$ KCP-10043F (OZ-001) by the chiral technique of supercritical fluid chromatography and assigned to their absolute configuration by the preparation of chiral diastereomers and ${ }^{1} \mathrm{H}$ NMR anisotropy method as well as the experimental ECD. The bacterial reverse mutation test (Ames test) for racemate KCP-10043F and its two enantiomers was performed to investigate their latent genotoxicities. All stereoisomers were fortunately found to be non-genotoxic against five bacterial strains with/without metabolic activation. In addition, $(R)-(-)$-KCP-10043F displayed almost equal cytotoxic activity to $(S)-(+)-\mathrm{KCP}-\mathbf{1 0 0 4 3 F}$ against three cancer cell lines. Based on these overall results, racemate $( \pm)$-KCP-10043F (OZ-001) could be used for our ongoing preclinical and clinical studies without the expensive asymmetric process and/or chiral separation. 


\section{Data Availability}

The supplementary materials (NMR spectrum, HPLC data, and Ames test data) used to support the findings of this study are included within the supplemental file.

\section{Conflicts of Interest}

The authors declare that there is no conflicts of interest regarding the publication of this paper.

\section{Authors' Contributions}

JunseongAhn, Dohyeong Ko. The contribution of the authors is equal.

\section{Acknowledgments}

This work was supported by ONCOZEN Co., Ltd., and the National Research Foundation of Korea (NRF) grant funded by the Korea government (MSIT) (No. 2019R1F1A1059332, No. 2020R1A5A2019413 and No. 2017R1A5A2014768).

\section{Supplementary Materials}

The supplementary materials (NMR spectrum, HPLC data, and Ames test data) used to support the findings of this study are included within the supplemental file. (Supplementary Materials)

\section{References}

[1] L. Song, M. Pan, R. Zhao, J. Deng, and Y. Wu, "Recent advances, challenges and perspectives in enantioselective release," Journal of Controlled Release, vol. 324, pp. 156-171, 2020.

[2] K. Gandhi, U. Shah, and S. Patel, "Drug stereochemistry: a prodigy for pharmacology and drug development," Current Drug Discovery Technologies, vol. 17, no. 5, pp. 565-573, 2020.

[3] H. Alkadi and R. Jbeily, "Role of chirality in drugs: an overview," Infectious Disorders-Drug Targets, vol. 18, no. 2, pp. 88-95, 2018.

[4] N. Vargesson, "Thalidomide-induced teratogenesis: history and mechanisms," Birth Defects Research Part C: Embryo Today-Reviews, vol. 105, no. 2, pp. 140-156, 2015.

[5] J. H. Kim and A. R. Scialli, "Thalidomide: the tragedy of birth defects and the effective treatment of disease," Toxicological Sciences, vol. 122, no. 1, pp. 1-6, 2011.

[6] M. Strong, "FDA policy and regulation of stereoisomers: paradigm shift and the future of safer, more effective drugs," Food and Drug Law Journal, vol. 54, no. 3, pp. 463-487, 1999.

[7] A. C. Egilman, A. D. Zhang, J. D. Wallach, and J. S. Ross, "Medicare Part D spending on single-enantiomer drugs versus their racemic precursors," Annals of Internal Medicine, vol. 171, no. 7, pp. 521-523, 2019.

[8] J. H. Kim, H. R. Jeong, D. W. Jung et al., "Synthesis and biological evaluation of fluoro-substituted 3,4-dihydroquinazoline derivatives for cytotoxic and analgesic effects," Bioorganic \& Medicinal Chemistry, vol. 25, no. 17, pp. 4656-4664, 2017.

[9] H.-K. Rim, S. Cho, D.-H. Shin et al., "T-type Ca2+ channel blocker, KYS05090 induces autophagy and apoptosis in A549 cells through inhibiting glucose uptake," Molecules, vol. 19, no. 7, pp. 9864-9875, 2014.

[10] H. B. Kang, H.-K. Rim, J. Y. Park et al., "In vivo evaluation of oral anti-tumoral effect of 3,4-dihydroquinazoline derivative on solid tumor," Bioorganic \& Medicinal Chemistry Letters, vol. 22, no. 2, pp. 1198-1201, 2012.

[11] J. S. Byun, J. M. Sohn, D. G. Leem et al., "In vitro synergistic anticancer activity of the combination of T-type calcium channel blocker and chemotherapeutic agent in A549 cells," Bioorganic \& Medicinal Chemistry Letters, vol. 26, no. 3, pp. 1073-1079, 2016.

[12] J.-H. Lee, H.-H. Lee, K. D. Ryu et al., "KCP10043F represses the proliferation of human non-small cell lung cancer cells by caspase-mediated apoptosis via STAT3 inactivation," Journal of Clinical Medicine, vol. 9, no. 3, p. 704, 2020.

[13] M. J. Frisch, G. W. Trucks, and H. B. Schlegel, Gaussian 09, Revision A.1, Gaussian Inc., Wallingford, CT, USA, 2009.

[14] J. McCann and B. N. Ames, "Detection of carcinogens as mutagens in the Salmonella/microsome test: assay of 300 chemicals: discussion," Proceedings of the National Academy of Sciences, vol. 73, no. 3, pp. 950-954, 1976.

[15] Xenometrix, Gewerbestrasse 25, CH-4123 Allschwil, Xenometrix, Allschwil, Switzerland.

[16] L. T. Taylor, "Supercritical fluid chromatography," Analytical Chemistry, vol. 82, no. 12, pp. 4925-4935, 2010.

[17] L. T. Taylor, "Supercritical fluid chromatography for the 21st century," The Journal of Supercritical Fluids, vol. 47, no. 3, pp. 566-573, 2009.

[18] S. Mane, "Racemic drug resolution: a comprehensive guide," Analytical Methods, vol. 8, no. 42, pp. 7567-7586, 2016.

[19] J. Sheehan, P. Cruickshank, and G. Boshart, "Notes-a convenient synthesis of water-soluble carbodiimides," Journal of Organic Chemistry, vol. 26, no. 7, pp. 2525-2528, 1961.

[20] J. R. Dunetz, J. Magano, and G. A. Weisenburger, "Large-scale Applications of amide coupling Reagents for the synthesis of pharmaceuticals," Organic Process Research \& Development, vol. 20, no. 2, pp. 140-177, 2016.

[21] S. Klod and E. Kleinpeter, "Ab initio calculation of the anisotropy effect of multiple bonds and the ring current effect of arenes-application in conformational and configurational analysis," Journal of the Chemical Society. Perkin Transactions, vol. 2, no. 10, pp. 1893-1898, 2001.

[22] B. Ranjbar and P. Gill, "Circular dichroism techniques: biomolecular and nanostructural analyses-a review," Chemical Biology \& Drug Design, vol. 74, no. 2, pp. 101-120, 2009.

[23] K.-I. Sugiyama, M. Yamada, T. Awogi, and A. Hakura, "The strains recommended for use in the bacterial reverse mutation test (OECD guideline 471) can be certified as non-genetically modified organisms," Genes and Environment, vol. 38, no. 1, p. 2, 2016.

[24] K. Mortelmans and E. Zeiger, "Mutation research/fundamental and molecular mechanisms of mutagenesis," Mutation Research: Fundamental and Molecular Mechanisms of Mutagenesis, vol. 455, no. 1, pp. 29-60, 2000.

[25] A. M. Sieuwerts, J. G. M. Klijn, H. A. Peters, and J. A. Foekens, "The MTT tetrazolium salt assay scrutinized: how to use this assay reliably to measure metabolie activity of cell cultures in vitro for the assessment of growth characteristics, IC50-values and cell survival," Clinical Chemistry and Laboratory Medicine, vol. 33, no. 11, pp. 813-823, 1995. 